\title{
Aeromonas hydrophila in tilapia (Oreochromis niloticus) after the intake of aflatoxins
}

\section{Aeromonas hydrophila em tilápia (Oreochromis niloticus) após a ingestão de aflatoxinas}

\author{
Samira Teixeira Leal de Oliveira ${ }^{1}$, Gisele Veneroni-Gouveia ${ }^{1}$, Janio Morais Santurio$^{2}$, \\ Mateus Matiuzzi da Costa'
}

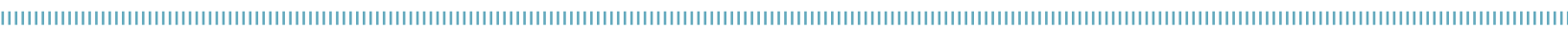

\begin{abstract}
The objectives of this study were to assess the effect of the intake of aflatoxin on the development of tilapia and to evaluate the impact of inoculation with Aeromonas hydrophila on performance parameters, so these two individual tests were performed. One hundred and twenty fingerlings aged 35 days old, with mean weight of $1.55 \pm 0.005 \mathrm{~g}$ and mean length of $5 \mathrm{~cm}$ were used in each test, distributed in 20 tanks. Each experimental unit consisted of a $60 \mathrm{~L}$ tank with six fingerlings. In the first experiment, increasing levels of aflatoxin $\left(0.350,0.757,1.177 \mathrm{mg} \mathrm{kg}\right.$ feed $\left.{ }^{-1}\right)$ were used as treatments and, for the control group, a diet without aflatoxin was used in a completely randomized design with four treatments and five replicates. In the second experiment, a control group of Nile tilapia fingerlings was used and received a diet without aflatoxin, inoculated with saline solution (group 1) and Aeromonas hydrophila (group 2), as well as groups of animals fed on diets containing 0.350 mg.kg feed ${ }^{-1}$ of aflatoxin (group 3), 0.757 mg.kg feed ${ }^{-1}$ of aflatoxin (group 4) and $1.177 \mathrm{mg} . \mathrm{kg} \mathrm{feed}^{-1}$ of aflatoxin (group 5), and these groups were inoculated with Aeromonas hydrophila. The survival rate and the total length of fingerlings were influenced by the treatments $(\mathrm{p}<0.05)$. The synergistic action of aflatoxins and Aeromonas hydrophila was effective and caused the death of experimental fish, thus affecting feed conversion and length.
\end{abstract}

KEYWORDS: fish; mycotoxin; opportunistic pathogen.
RESUMO: Os objetivos deste estudo foram analisar o consumo de aflatoxinas sobre o desenvolvimento de alevinos de tilápia e avaliar o efeito da inoculaçáo de Aeromonas hydrophila sobre os parâmetros de desempenho produtivo dos animais. Para isso, dois testes individuais foram realizados. Foram utilizados 120 alevinos com 35 dias e $1,55 \pm 0,005 \mathrm{~g}$ de peso médio em cada ensaio, distribuídos em 20 aquários. Cada unidade experimental foi constituída por um aquário de $60 \mathrm{~L}$ com seis alevinos. No primeiro ensaio, como tratamentos foram utilizados níveis crescentes de inclusão de aflatoxina $(0,350$; 0,757; 1,177 mg.kg ração ${ }^{-1}$ ) e um grupo controle com ração sem aflatoxina, em um delineamento inteiramente randomizado com quatro tratamentos e cinco repetiçóes. No segundo ensaio, utilizou-se um grupo controle que recebeu ração livre de aflatoxina, o qual foi inoculado com solução salina (grupo 1) e Aeromonas hydrophila (grupo 2), bem como grupos de animais que receberam ração contendo 0,350 mg.kg feed ${ }^{-1}$ de aflatoxina (grupo 3); 0,757 mg.kg feed $^{-1}$ de aflatoxina (grupo 4); e 1,177 mg.kg ração ${ }^{-1}$ de aflatoxina (grupo 5), sendo estes grupos inoculados com Aeromonas hydrophila. A sobrevivência e o comprimento total dos alevinos foram influenciados pelos tratamentos ( $\mathrm{p}<0,05)$. A ação sinérgica de aflatoxinas e Aeromonas hydrophila mostrou-se eficaz ao provocar a morte dos alevinos e influenciar a conversão alimentar e comprimento.

PALAVRAS-CHAVE: peixe; micotoxina; patógeno oportunista.

\footnotetext{
'Laboratório de Microbiologia e Imunologia Animal; Universidade Federal do Vale do São Francisco (UNIVASF) - Petrolina (PE), Brazil. ${ }^{2}$ Laboratório de Pesquisas Micológicas (LAPEMI); Departamento de Microbiologia; Universidade Federal de Santa Maria (UFSM) - Santa Maria (RS), Brazil. *Corresponding author: mateus.costa@univasf.edu.br 


\section{INTRODUCTION}

Despite the long tradition and practice of fish farming in some countries throughout the world, it is still considered as a new food production sector, but one that has grown rapidly over the past 50 years. In the period from 1970 to 2008 , the production of fish for consumption increased an average of $8.3 \%$ per year. In Latin America, Brazil has made progress and is now recognized as one of the countries with the greatest water potential in the world (FAO, 2010).

Despite the increasing development of aquaculture around the world, some barriers still need to be dealt with, such as the inadequate nutrition of the animals. The presence of mycotoxins, such as aflatoxins, in feed is a factor that can lead to lowering the immune response in fish. Aflatoxins are toxic metabolic products produced by Aspergillus flavus and A. parasiticus (BenNetT; KLich, 2003). They are common feed contaminants in corn, peanut meal and cotton seed meal, which can be used to produce feed (El-SaYed; Khalil, 2009). They can make fish more susceptible to stress of any kind, presenting toxicologic manifestations and effects on the immune system, and they may also cause chronic and acute effects (Miller; Trenholm, 1997). When homeostasis is disturbed, fish become highly vulnerable to infections, which may be caused by opportunistic pathogens, required or facultative, and these may be present in the culture environment (RoberTs, 1981). The involvement of Aeromonas spp. in sickness is usually associated with other conditions, and its pathogenicity appears to be related to the stress of debilitated hosts. Species of Aeromonas spp. mesophilic, mainly A. hydrophila, have been associated with economic losses throughout the world (Janda; Аввотt, 2010).

Currently, the Aeromonas genus is considered to be associated with aquatic environments, being isolated from drinking water, waste water and sewage in various stages of treatment (JANDA; АввотT, 2010).
The purpose of this study was to evaluate the effect of increasing levels of aflatoxin in the feed of Nile tilapia and the effect of inoculation on Aeromonas hydrophila after providing increasing levels of aflatoxin in feed.

\section{MATERIAL AND METHODS}

\section{Animals}

Male Nile tilapia fingerlings aged approximately 35 days old, with mean weight of $1.55 \pm 0.005 \mathrm{~g}$, mean length of $5 \mathrm{~cm}$ and originated from the Integrated Center for Fishery Resources (Centro Integrado de Recursos Pesqueiros - CIRPA), Petrolina (PE), Brazil, were used. The animals $(\mathrm{n}=120)$ were distributed in 20 tanks with $60 \mathrm{~L}$ working volume in a completely randomized design. Therefore, each experimental unit consists of one tank with six fingerlings.

The tanks had constant aeration. The experiment was managed by daily siphoning in the morning (at 7 a.m.) and afternoon (at 4:30 p.m.), with the removal of $40 \%$ of water, of the feces and any remaining feed. The internal cleaning of the tank walls was measured daily to prevent the proliferation of periphyton.

This work was approved by the Ethics Committee for Research in Human and Animal Studies at Univasf, report number 27091053, of October 6, 2010.

\section{Diet}

Four diets were formulated with $30 \%$ digestible protein and $3,000 \mathrm{kcal}$ of digestible energy (Table 1). To prepare the diets, the feed was ground through a $1 \mathrm{~mm}$ sieve, moistened, pelleted in an experimental electrical pelletizer, and then pellets were dried in a forced air circulation oven for $24 \mathrm{~h}$ at

Table 1. Composition of experimental feeds.

\begin{tabular}{|c|c|c|c|c|}
\hline Ingredients* & & Conc & on $(\%)$ & \\
\hline Aflatoxin mg.kg feed ${ }^{-1}$ & 0.00 & 0.350 & 0.757 & 1.177 \\
\hline Soybean meal & 70.79 & 70.79 & 70.79 & 70.79 \\
\hline Maize & 16.70 & 16.70 & 16.70 & 16.70 \\
\hline Soybean oil & 5.00 & 5.00 & 5.00 & 5.00 \\
\hline Dicalcic phosphate & 2.80 & 2.80 & 2.80 & 2.80 \\
\hline Calcitic lime & 0.20 & 0.20 & 0.20 & 0.20 \\
\hline Mineral and vitamin supplement** & 4.00 & 4.00 & 4.00 & 4.00 \\
\hline Salt & 0.50 & 0.50 & 0.50 & 0.50 \\
\hline Butylated hydroxytoluene (BHT) & 0.01 & 0.01 & 0.01 & 0.01 \\
\hline Total & 100.00 & 100.00 & 100.00 & 100.00 \\
\hline
\end{tabular}

*According to RosTAGNo et al. (2000); **Guaranteed levels per kilogram of product: Vitamin A - 1,200,000 IU; Vitamin D3, 200,000 IU; Vitamin E - 12,000 mg; Vitamin K3 - 2400 mg; Vitamin B1 - 4800 mg; Vitamin B2 - 4800 mg; Vitamin B6 - 4000 mg; Vitamin B 12 - 4800 mg; Folic acid - 1200 mg; Calcium pantothenate - 12,000 mg; Vitamin C - 48,000 mg; Biotin - 48 mg; Choline - 65,000 mg; Niacin - 24,000 mg; $\mathrm{Fe}$ - 10,000 mg; Cu - 6000 mg; Mn - 4000 mg; Zn - 6000 mg; I - 20mg; Co - 2 mg; Se - 20 mg. 
$56^{\circ} \mathrm{C}$. They were then fragmented to fit the mouth of the fingerlings.

The aflatoxin added to the feed was obtained by dry fermentation with the Aspergillus parasiticus fungus (NRRL 2999) in sterile rice. After being grounded and quantified, its inclusion was made by the premixing in the maize fraction, prior to mixing the other feed ingredients.

Feeding was performed three times a day, at 8 a.m, at noon and at 5 p.m. Every week, the experimental units were weighed to provide a suitable amount of feed. The supplied feed was the same in the two phases of the experiment for their respective treatments.

The aflatoxin added to feed was obtained by dry fermentation with the Aspergillus parasiticus fungus (NRRL 2999) in sterile rice. After ground and quantified, its inclusion was made by premixing in the maize fraction, prior to mixing the other feed ingredients.

\section{Test 1: Effect of aflatoxin on the performance of Nile tilapia}

Treatments used to evaluate the effect of aflatoxins on Nile tilapia fingerlings consisted of four feeds, one control (without the addition of aflatoxin) and three others with increasing levels of aflatoxin $\left(0.350,0.757\right.$ and $1.177 \mathrm{mg}^{\mathrm{kg}}$ feed $\left.^{-1}\right)$. The experimental model was designed in four treatments and five replications. Feed was supplied at a level of $8 \%$ of the biomass.

Daily, in the morning and in the afternoon, before siphoning, the oxygen concentration, temperature, electrical conductivity and the $\mathrm{pH}$ of the tank water were measured. After 30 days of experiment, the animals were weighed to determine the parameters of growth, weight gain and apparent feed conversion.

\section{Test 2: Effect of aflatoxin on the virulence of Aeromonas hydrophila in Nile tilapia}

For this experiment, five treatments and four replications were used. The treatments considered were: a group of Nile tilapia fingerlings that received feed without aflatoxin and was inoculated with saline solution (group 1); a group that received feed without aflatoxin and was inoculated with Aeromonas hydrophila (group 2); a group that received a diet containing $0.350 \mathrm{mg} \cdot \mathrm{kg}^{-1}$ of aflatoxin and was inoculated with Aeromonas hydrophila (group 3); a group that received a diet containing $0.757 \mathrm{mg} \cdot \mathrm{kg}^{-1}$ of aflatoxin and was inoculated with Aeromonas hydrophila (group 4); and a group that received a diet containing $1.177 \mathrm{mg} \cdot \mathrm{kg}^{-1}$ of aflatoxin and was inoculated with Aeromonas hydrophila (group 5). The isolated Aeromonas hydrophila was obtained from Lophiosilurus alexandri, from CIRPA (Petrolina/PE, Brazil).
Each experimental unit consisted of a tank containing six fish. Feed was supplied at a level of $8 \%$ of the biomass.

After 30 days of supplying feed, when the fishes were with mean weight of $8.29 \pm 0.82 \mathrm{~g}$, the inoculation of the Aeromonas hydrophila in tilapia Nile was performed by means of a bacterial inoculum prepared in dilution with sterile saline solution to a concentration of $10^{8} \mathrm{CFU} / \mathrm{mL}$. This solution was intramuscularly injected at the rate of $0.5 \mathrm{~mL} /$ animal, lateral-dorsal right. Pure saline $(0.65 \%)$ solution was injected in a similar fashion (BOIJINK; BRANDÃo, 2001).

The physical-chemical parameters of the water from the tanks were also daily measured in this experiment, in the morning (at 7 a.m.) and in the afternoon (at 4:30 p.m.). Before the inoculation of $A$. hydrophila in the fish, a culture of tank water was made in blood Agar to check for the possible presence of bacteria in the aquatic environment itself. After inoculation, the animals were evaluated for possible manifestations of infection by Aeromonas hydrophila (external lesions, ascites etc.) and mortality for two weeks. At the end of the test period, after being anesthetized with benzocaine $(100 \mathrm{mg} / \mathrm{L})$ and euthanized by medullar section, the fishes of each experimental unit were weighed and measured to determine the performance and carcass parameters (final weight, apparent feed conversion, weight gain, standard length, total length, width, final height, carcass yield, carcass yield without head). Two fishes from each experimental unit had their liver extracted in order to determine the hepatosomatic index (IHS) [(liver weight / body weight) x 100], and for one of them a bacterial culture of the kidney was made in Tryptone Soya Agar (TSA). The culture in TSA was also performed for all the fishes killed as a result of inoculation. Then, we proceeded with the biochemical characterization of the isolates (Quinn et al., 1994).

After all the proposed parameters were assessed, and when the performance values, survival rate, carcass parameters and IHS were calculated, as well as all the physicalchemical parameters of the water, data were subjected to analysis of variance (One-way ANOVA). In the event of significant effect, the Tukey's test $(\mathrm{p}<0.05)$ was carried out with the software Statistica 7.0.

\section{RESULTS}

\section{Effect of aflatoxin on the performance of Nile tilapia}

\section{Tank water and bacterial culture}

The mean values for temperature, $\mathrm{pH}$, dissolved oxygen and electrical conductivity, in the morning and in the afternoon, were $27.28 \pm 0.06^{\circ} \mathrm{C}$ and $28.14 \pm 0.12^{\circ} \mathrm{C} ; 7.24 \pm 0.04$ 
and $7.14 \pm 0.04 ; 6.94 \pm 0.11 \mathrm{mg} / \mathrm{L}$ and $6.73 \pm 0.17 \mathrm{mg} / \mathrm{L}$; $68.87 \pm 2.75 \mu \mathrm{Sm} / \mathrm{cm}$ and $63.71 \pm 3.68 \mu \mathrm{Sm} / \mathrm{cm}$, respectively. There was no variation in these parameters among treatments $(\mathrm{p}>0.05)$.

\section{Survival, growth and feed conversion}

During the experimental period, the survival rate was of $100 \%$ in all units. The initial weight, growth and feed conversion averages of tilapia fingerlings submitted to diets with increasing levels of aflatoxin are presented in Table 2. The initial weight of fingerlings used in the experiment was statistically similar among treatments ( $p>0.05$ ). The final weight, weight gain and feed conversion averages showed no significant differences among treatments $(\mathrm{p}>0.05)$.

\section{Effect of aflatoxin on the virulence of A. hydrophila in Nile tilapia}

\section{Tank water and bacterial culture}

Mean values for temperature, $\mathrm{pH}$, dissolved oxygen and electrical conductivity, in the morning and in the afternoon, were $27.31 \pm 0.09^{\circ} \mathrm{C}$ and $28.14 \pm 0.12^{\circ} \mathrm{C} ; 7.2 \pm 0.05$ and $7.14 \pm 0.05 ; 7.14 \pm 0.15 \mathrm{mg} / \mathrm{L}$ and $6.76 \pm 0.15 \mathrm{mg} / \mathrm{L}$; $86.81 \pm 0.63 \mu \mathrm{Sm} / \mathrm{cm}$ and $82.58 \pm 4.5 \mu \mathrm{Sm} / \mathrm{cm}$, respectively. There was no variation of these parameters among treatments ( $p>0.05)$.

There was no growth of Aeromonas spp. from the tank water. The bacterial culture of the fish that died during the experimental period showed the growth of bacterial colonies of Aeromonas; however, the same was not observed for the culture from the fingerlings' kidney at the end of the experiment.

\section{Survival rate, growth and feed conversion}

Under the conditions of this experiment, the animals died after 24 hours, those that underwent necropsy showed ascites, as well as purulent and bleeding external lesions. Seventytwo hours after inoculation, the necrosis of the caudal fin was also observed.
The survival percentages of Nile tilapia fingerlings submitted to diets with increasing levels of aflatoxin and inoculated with $A$. hydrophila are shown in Figure 1. Survival was influenced by the treatments; survival rate was higher for the treatment in which the fishes received feed without aflatoxin and were inoculated with saline solution (T1) $(\mathrm{p}<0.05)$ in comparison with the other treatments, which did not differ among each other.

The mean final weight and weight gain values showed no significant differences between treatments according to aflatoxin doses ( $\mathrm{p}>0.05)$ and inoculation with saline or $A$. hydrophila.

The mean values of apparent feed conversion of Nile tilapia fingerlings are demonstrated in Figure 2. Their values showed significant differences $(\mathrm{p}<0.05)$ between groups that were fed without aflatoxin and inoculated with saline solution (Treatment 1) and the group that received diets containing $1.177 \mathrm{mg} \cdot \mathrm{kg}^{-1}$ of aflatoxin and was inoculated with Aeromonas hydrophila (Treatment 5); mean value was lower for treatment 1 .

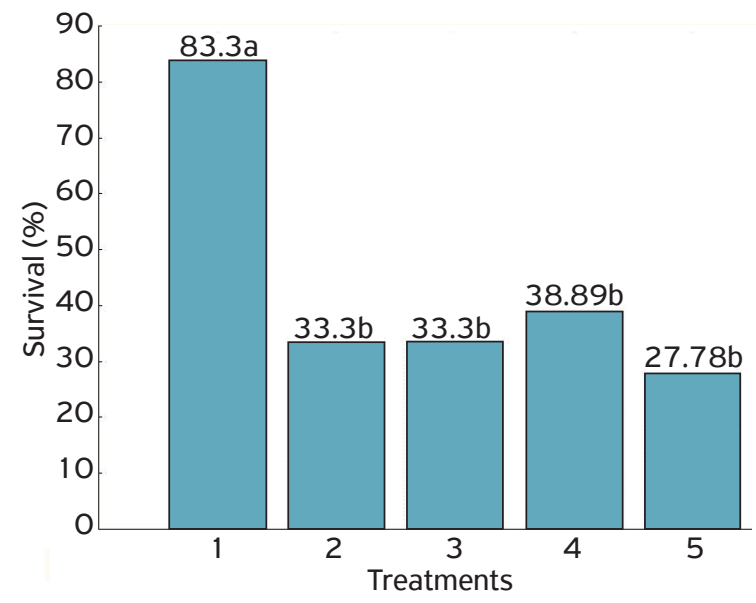

(1) group of fingerlings receiving control diet and inoculated with saline solution; (2) control diet and inoculated with A. hydrophila; (3) diet containing $0.350 \mathrm{mg} . \mathrm{kg}^{-1}$ of aflatoxin and inoculated with A. hydrophila; (4) diet containing $0.757 \mathrm{mg} . \mathrm{kg}^{-1}$ of aflatoxin and inoculated with $A$. hydrophila; (5) diet containing $1.177 \mathrm{mg}^{-\mathrm{kg}^{-1}}$ of aflatoxin and inoculated with $A$. hydrophila.

Treatments with different letters are significantly different.

Figure 1. Survival of Nile tilapia (Oreochromis niloticus) fingerlings subjected to challenges with increasing doses of aflatoxin and inoculated with $A$. hydrophila.

Table 2. Mean values of performance parameters and apparent feed conversion of Nile tilapia fingerlings submitted to diets with increasing levels of aflatoxins.

\begin{tabular}{lccccc} 
& \multicolumn{5}{c}{ Aflatoxin mg.kg feed $^{-1}$} \\
Parameters & 0.00 & 0.350 & 0.757 & 1.177 & p-value \\
\cline { 2 - 5 } Initial weight $(\mathrm{g})$ & $1.55 \pm 0.01$ & $1.55 \pm 0.00$ & $1.55 \pm 0.01$ & $1.55 \pm 0.01$ & 0.25 \\
\hline Final weight $(\mathrm{g})$ & $8.52 \pm 0.58$ & $8.26 \pm 0.99$ & $8.39 \pm 0.80$ & $8.00 \pm 1.01$ & 0.81 \\
\hline Weight gain (g) & $6.96 \pm 3.48$ & $6.71 \pm 5.95$ & $6.83 \pm 4.81$ & $6.45 \pm 6.06$ & 0.81 \\
\hline AFC & $1.08 \pm 0.04$ & $1.11 \pm 0.08$ & $1.09 \pm 0.05$ & $1.13 \pm 0.09$ & 0.56 \\
\hline
\end{tabular}

AFC: apparent feed conversion. 


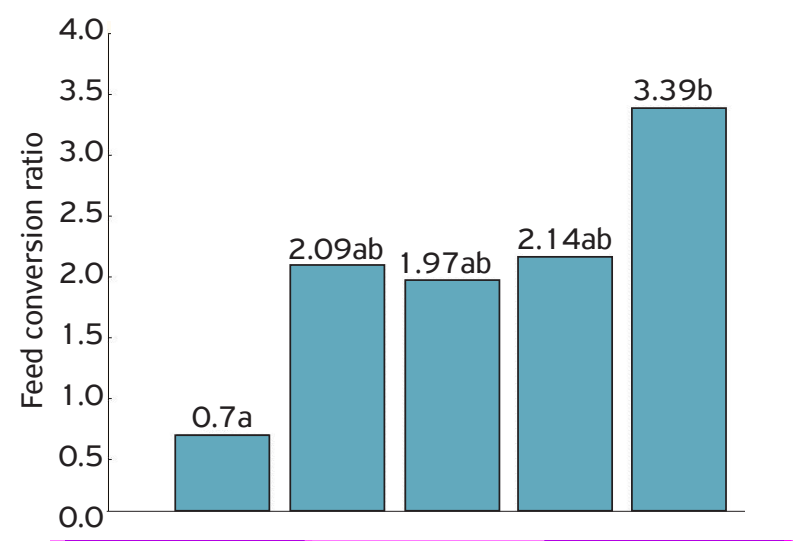

(1) group that received control diet and was inoculated with saline solution; (2) on control diet and inoculated with A. hydrophila; (3) diet containing $0.350 \mathrm{mg} . \mathrm{kg}^{-1}$ of aflatoxin and inoculated with A. hydrophila; (4) diet containing $0.757 \mathrm{mg}^{\mathrm{kg}} \mathrm{g}^{-1}$ of aflatoxin and inoculated with $A$. hydrophila; (5) diet containing $1.177 \mathrm{mg}^{\mathrm{kg}}{ }^{-1}$ of aflatoxin and inoculated with $A$. hydrophila.

Treatments with different letters are significantly different.

Figure 2. Apparent feed conversion of Nile tilapia fingerlings (Oreochromis niloticus) subjected to challenges with increasing doses of aflatoxin and inoculated with $A$. hydrophila.

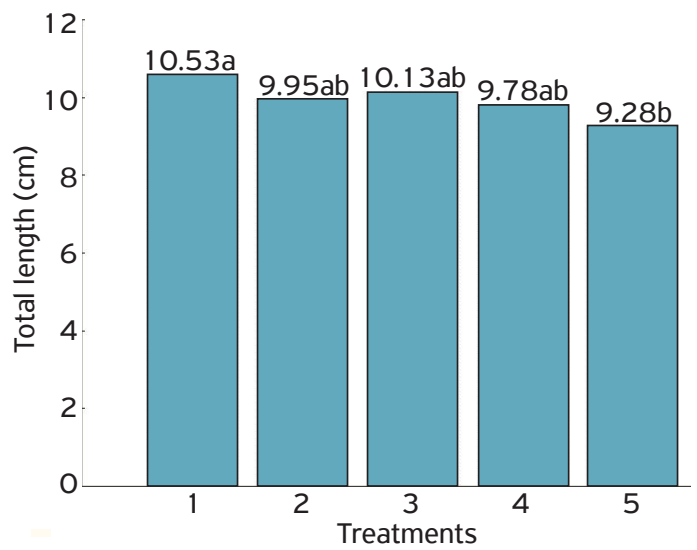

(1) group receiving control diet and inoculated with saline solution; (2) control diet and inoculated with A. hydrophila; (3) diet containing $0.350 \mathrm{mg}^{\mathrm{kg}} \mathrm{kg}^{-1}$ of aflatoxin and inoculated with A. hydrophila; (4) diet containing $0.757 \mathrm{mg} \cdot \mathrm{kg}^{-1}$ of aflatoxin and inoculated with A. hydrophila; (5) diet containing $1.177 \mathrm{mg}^{-\mathrm{kg}^{-1}}$ of aflatoxin and inoculated with $A$. hydrophila.

Treatments with different letters are significantly different.

Figure 3. Total length $(\mathrm{cm})$ of Nile tilapia fingerlings (Oreochromis niloticus) that were subjected to challenges with increasing doses of aflatoxin and inoculated with A. hydrophila.

\section{Carcass characteristics}

The final results of standard length, width, height, body width and carcass yield with and without including the head of the fingerlings are found in Table 3. The mean body parameters showed no significant differences between treatments $(p>0.05)$.

The total length of the animals is shown in Figure 3. The total length of treatment 1 (the group on the diet without aflatoxin and inoculated with saline solution) was significantly greater $(\mathrm{p}<0.05)$ in relation to treatment 5 (group that received the diet containing $1.177 \mathrm{mg} \cdot \mathrm{kg}^{-1}$ aflatoxin and was inoculated with Aeromonas hydrophila).

\section{Hepatosomatic index and condition factor}

The values of hepatosomatic index and condition factor of fingerlings are shown in Table 4. There was no significant effect on the hepatosomatic index and the condition factor in animals $(\mathrm{p}>0.05)$.

\section{DISCUSSION}

Mean values of physical-chemical parameters of tank water, $\mathrm{pH}$, dissolved oxygen, electrical conductivity and morning and evening temperatures remained within appropriate limits for the species (EL-SAYED, 2006).

The analysis of performance and carcass parameters showed no differences between the group fed with aflatoxin and the control in test 1 of this study. Deng et al. (2010), after evaluating the effect of aflatoxins on the tilapia diet for a period of 20 weeks, did not observe toxic effects when administered at concentrations of $1.6 \mathrm{mg} / \mathrm{kg}$, thus attributing this to good growing conditions. However, EL-SAYED and KHALIL (2009) demonstrated acute toxic effects and changes in behavior among sea bass (Dicentrarchus labrax L.) fed with aflatoxin at concentrations of $0.018 \mathrm{mg} / \mathrm{kg}$, which were lower than those used in our study. The quantities of aflatoxin used in this study correspond to estimated values of $\mathrm{DL}_{50}$ for all animal species (0.3 to $9.0 \mathrm{mg} / \mathrm{kg}$ ) (MCKEAN et al., 2004).

According to TuAn et al. (2002), doses of aflatoxin above $2.5 \mathrm{mg} / \mathrm{kg}$ in the diet of Nile tilapia may adversely affect growth parameters, with mortality associated with the intake of aflatoxins, which can be observed in doses up to $100 \mathrm{mg} . \mathrm{kg} \mathrm{feed}^{-1}$. Lopes et al. (2005) observed a decrease in the growth of silver catfish fingerlings (Rhamdia quelen) fed on a diet containing aflatoxin at a concentration of $0.204 \mathrm{mg} / \mathrm{kg}$, but no effect was observed on the survival of fishes even when doses of $1.177 \mathrm{mg} / \mathrm{kg}$ were administered.

The sensitivity of fish to mycotoxins is variable, and the rainbow trout species exhibits more sensitivity (BAILEY et al., 1996). Arana et al. (2002) showed that the trout genotype can significantly affect the effect of aflatoxins on growth parameters and weight gain. The catfish is a resistant fish (JaNTRAROTAI; Lovell, 1991), which was also confirmed by Lopes et al. (2005) after evaluating the effect of aflatoxins on catfish. This indicates the importance of the impact of the species and intrinsic genetic components on the effects caused by micotoxins on fish, and this may explain some of the results described in this study.

The isolate from $A$. hydrophila used in test 2 of this study was effective for causing the death of the fish, which is in agreement with several reports in literature which indicate this bacterium as being the main pathogen of aquatic organisms (BoIjInK; BrandÃo, 2001, 2004; KubitZA; 
Table 3. Mean final values of body parameters of Nile tilapia subjected to challenges with increasing doses of aflatoxin and inoculated with $A$. hydrophila.

\begin{tabular}{lrrrrrr} 
& \multicolumn{5}{c}{ Treatments } \\
\cline { 2 - 7 } Parameters & 1 & 2 & 3 & 4 & 5 & p-value \\
\hline Standard length $(\mathrm{cm})$ & $8.24 \pm 0.09$ & $8.38 \pm 0.43$ & $8.35 \pm 0.25$ & $8.18 \pm 0.53$ & $7.67 \pm 0.26$ & 0.11 \\
\hline Width $(\mathrm{cm})$ & $1.53 \pm 0.03$ & $1.53 \pm 0.08$ & $1.55 \pm 0.10$ & $1.48 \pm 0.02$ & $1.38 \pm 0.11$ & 0.06 \\
\hline Final height $(\mathrm{cm})$ & $3.05 \pm 0.07$ & $2.98 \pm 0.02$ & $3.15 \pm 0.20$ & $2.96 \pm 0.08$ & $2.84 \pm 0.22$ & 0.15 \\
\hline Carcass yield $(\mathrm{g})$ & $15.32 \pm 0.91$ & $15.77 \pm 1.69$ & $15.86 \pm 1.91$ & $14.60 \pm 1.49$ & $13.90 \pm 2.64$ & 0.61 \\
\hline Carcass yield without head $(\mathrm{g})$ & $10.84 \pm 0.78$ & $11.45 \pm 1.51$ & $11.44 \pm 1.58$ & $10.22 \pm 1.25$ & $8.67 \pm 1.01$ & 0.06 \\
\hline
\end{tabular}

(1) group receiving control diet and inoculated with saline solution; (2) control diet and inoculated with A. hydrophila; (3) diet containing

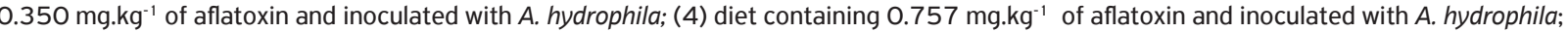
(5) diet containing $1.177 \mathrm{mg} . \mathrm{kg}^{-1}$ of aflatoxin and inoculated with $A$. hydrophila.

Table 4. Hepatosomatic index and condition factor of Nile tilapia subjected to challenges with increasing doses of aflatoxin and inoculated with $A$. hydrophila.

\begin{tabular}{lccccccc} 
& \multicolumn{5}{c}{ Treatments $^{1}$} \\
\cline { 2 - 7 } Parameters & 1 & 2 & 3 & 4 & 5 & p-value \\
HSI & $1.25 \pm 0.4$ & $1.14 \pm 0.34$ & $1.98 \pm 0.62$ & $1.42 \pm 0.22$ & $1.35 \pm 0.55$ & 0.24 \\
\hline CF & $1.75 \pm 0.03$ & $1.48 \pm 0.15$ & $1.73 \pm 0.02$ & $1.77 \pm 0.25$ & $1.82 \pm 0.11$ & 0.11 \\
\hline
\end{tabular}

(1) group receiving control diet and inoculated with saline solution; (2) control diet and inoculated with $\mathrm{A}$. hydrophila; (3) diet containing 0.350 mg. $\mathrm{kg}^{-1}$ of aflatoxin and inoculated with $A$. hydrophila; (4) diet containing $0.757 \mathrm{mg} . \mathrm{kg}^{-1}$ of aflatoxin and inoculated with A. hydrophila; (5) diet containing $1.177 \mathrm{mg} . \mathrm{kg}^{-1}$ of aflatoxin and inoculated with A. hydrophila. HSI: hepatosomatic index; CF: condition factor.

Kubitza, 2004; Pavanelli et al., 2008; Plumb; Hanson, 2011). The death of the animals 24 hours after the challenge with necropsy showed ascites, as well as purulent and bleeding external lesions. Seventy-two hours after the inoculation, with the fishes presenting necrosis of the caudal fin, results were similar to those described for septicemic infections caused by Aeromonas spp. in other studies (Boijink et al., 2001; Boijink; Brandão, 2001, 2004).

After bacterial inoculation, significant differences were observed between the control group and those fed with aflatoxin at $1.177 \mathrm{mg} \cdot \mathrm{kg}^{-1}$ for feed conversion and total length. These results indicate the synergistic action between aflatoxins and Aeromonas hydrophila. The effect of aflatoxins on the liver and immune system is well known, causing a great deal of damage to the metabolism of proteins, carbohydrates and lipids (Mallmann et al., 1994; Rosmaninho et al., 2001; Bennett; Klich, 2003). The fishes receiving aflatoxin become sensitive to stress due to environmental and microbial factors (RosmaninHo et al., 2001; Lopes et al., 2005). It is believed that the same may have occurred in our study, with reduced parameters of apparent feed conversion and total length. In the present study, there was no change in the hepatosomatic index, which would suggest liver damage.

Currently, intensive systems of Nile tilapia production are associated with stress, overstocking and administration of diets containing products of plant origin (Cyrino et al., 2004; Hussain, 2004; Pavanelli et al.,
2008). This fact predisposes fish to aflatoxin contamination, described as feed contaminants produced by various aquatic organisms, possibly reaching levels of 3.388 g (Abdelhamid et al., 1998; Farabi et al., 2006). This is a cause for concern, especially when considering the effects of interaction of this contaminant with fish pathogens, such as viruses and bacteria (Rosmaninho et al., 2001).

\section{CONCLUSION}

It was observed that doses up to $1.177 \mathrm{mg} \cdot \mathrm{kg} \mathrm{feed}^{-1}$ of aflatoxin do not affect the performance and carcass yield of Nile tilapia fingerlings. However, the synergistic action of aflatoxins and Aeromonas hydrophila strongly affects feed conversion and the length of the fish.

\section{ACKNOWLEDGMENTS}

To CAPES (Coordination for the Improvement of Higher Education), for granting a graduate study scholarship to Samira Teixeira Leal de Oliveira. To the Integrated Center for Fishery Resources (CIRPA) of Bebedouro, PE, Brazil for providing the Nile tilapia. 


\section{REFERENCES}

ABDELHAMID, A.M.; KHALIL, F.F.; RAGAB, M.A. Problem of mycotoxins in fish production. Egyptian Journal of Nutrition and Feeds, v.1, n. 1, p.63-71, 1998.

ARANA, S.; TABATA, Y.A.; SABINO, M. Differential effect of chronic aflatoxin $B_{1}$ intoxication on the growth performance and incidence of hepatic lesions in triploid and diploid rainbow trout (Oncorhynchus mykiss). Arquivos de Medicina Veterinária, v.34, p.253-263, 2002.

BAILEY, G.S.; WILLIAMS, D.E.; HENDRICKS, J.D. Fish models for environmental carcinogenesis: the rainbow trout. Environmental Health Perspectives, v.104, p.5-21, 1996.

BENNETT, J.W.; KLICH, M. Mycotoxins. Clinical microbiology reviews, v. 16, n.3, p.497-516, 2003.

BOIJINK, C.L.; BRANDÃO, D.A.; VARGAS, A.C.; COSTA, M.M.; RENOSTO, A.V. Inoculação de suspensão bacteriana de Plesiomonas shigelloides em jundiá, Rhamdia quelen (teleostei: pimelodidae). Ciência Rural, v.31, n.3, p.497-501, 2001.

BOIJINK, C.L.; BRANDÃO, D.A. Avaliação de suspensões bacterianas de Aeromonas hydrophila, em juvenis de jundiá, Rhamdia quelen (Teleostei: Pimelodidae). Biodiversidade Pampeana, PUCRS, v.28, p.2:3-8, 2004.

Inoculação Bacteriana de Aeromonas hydrophila e a Sobrevivência de juvenis de jundiá, Rhamdia quelen (Teleostei: Pimelodidae). Ciência Rural, v.31, n.3, p.503-507, 2001.

CYRINO, J.E.P.; URBINATI, E.C.; FRACALOSSI, D.M.; CASTAGNOLLI, N. Tópicos especiais em piscicultura de áqua doce tropical intensiva. São Paulo: TecArte, 2004. 533p.

DENG, S.; TIAN, L.; LIU, F.; JIN, S.; LIANG, G.; YANG, H.; DU, Z.; LIU, Y. Toxic effects and residue of aflatoxin $B_{1}$ in tilapia (Oreochromis niloticus $x$ O. aureus) during long-term dietary exposure. Aquaculture, v.307, p.233-240, 2010.

EL-SAYED, A.F.M. Tilapia Culture. Oceanography Department, Faculty of Science. Alexandria: Alexandria University, Egypt. 2006.

EL-SAYED, Y.S.; KHALIL, R.H. Toxicity, biochemical effects and residue of aflatoxin $B_{1}$ in marine water-reared sea bass (Dicentrarchus labrax L.). Food and Chemical Toxicology, v.47, p. 1606-1609, 2009.

FAO - Food and Agriculture Organization. El estado mundial de la pesca y la acuicultura 2010 (in Spanish). Rome: Food and Agriculture Organization of the United Nations. 2010, 242p.

FARABI, S.M.; YOUSEFIAN, M.; HAJIMORADLOO, A. Aflatoxicosis in juvenile Huso huso fed a contaminated diet. Journal of Applied Ichthyology, v.22, Suppl.1, p.234-237, 2006.
HUSSAIN, M.G. Farming of tilapia: breeding plans, mass seed production and aquaculture techniques. Bangladesh Fisheries Research Institute. 2004. 149p.

JANDA, J.M.; ABBOTT, S.L. The Genus Aeromonas: Taxonomy, Pathogenicity, and Infection. Clinical Microbiology Reviews, v.23, n. 1, p.35-73, 2010.

JANTRAROTAI, W.; LOVELL, B.T. Subchronic toxicity of aflatoxin B1 to channel catfish. Journal of Aquatic Animal Health, v.2, p.248-275, 1991.

KUBITZA, F.; KUBITZA, L.M.M. Principais parasitoses e doenças dos peixes cultivados. 4. ed. Jundiá (SP). 2004. $118 p$.

LOPES, P.R.S.; NETO, J.R.; MALLMANN, C.A.; LAZZARI, R.; PEDRON, F.A.; VEIVERBERG, C.A. Crescimento e alterações no fígado e na carcaça de alevinos de jundiá alimentados com dietas com aflatoxinas. Pesquisa agropecuária brasileira, v.40, n.10, p.1029-1034, 2005.

MALLMANN, C.A.; SANTURIO, J.M.; WENTZ, L. Aflatoxinas: aspectos clínicos e toxicológicos em suínos. Ciência Rural, v.24, n.3, p.635-643, 1994.

MCKEAN, C.; TANG, L.; TANG, M.; BILLAM, M.; WANG, Z.; THEODORAKIS, C.W.; KENDALL, R.J.; WANG, J.S. Comparative acute and combinative toxicity of aflatoxin $\mathrm{B} 1$ and fumonisin $\mathrm{B}_{1}$ in animals and human cells. Food and Chemical Toxicology, v.44, p.868-876, 2004

MILLER, J.D.; TRENHOLM, H.L. Mycotoxins in grain: compounds other than aflatoxin. Minnesota: Eagan, 1997. 552p.

PAVANELLI, G.C.; EIRAS, J.C.; TAKEMOTO, R.M. Doenças de Peixes: profilaxia, diagnóstico e tratamento. 3. ed. Maringá: Eduem. 2008. $311 \mathrm{p}$.

PLUMB, J.A.; HANSON, A. Health maintenance and principal microbial diseases of cultured fishes. Blackwell Publishing, 3. ed. $2011.506 \mathrm{p}$.

ROBERTS, R.J. Patologia de los peces. 1981. 365p.

ROSMANINHO, J.F.; OLIVEIRA, C.A.F.; BITTENCOURT, A.B.F. Efeitos das micotoxicoses crônicas na produção avícola. Arquivos do Instituto de Biologia, v.68, p.107-114, 2001.

ROSTAGNO, H.S.; ALBINO, L.F.T.; GOMES, P.C.; OLIVEIRA, R.F.; LOPES, D.C. Tabelas Brasileiras para aves e suínos: composição de alimentos e exigências nutricionais. Viçosa: Editora UFV. 2000. $141 \mathrm{p}$.

TUAN, N.A.; GRIZZLE, J.M.; LOVELL, R.T.; MANNING, B.B.; ROTTINGHAUS, G.E. Growth and hepatic lesions of Nile tilapia (Oreochromis niloticus) fed diets containing aflatoxin $B_{1}$. Aquaculture, v.212, p.311-319, 2002. 